\title{
The Electability Level of PDI-P on Social Media of Instagram
}

\author{
${ }^{1}$ RESKY EKA RACHMANDANI, ${ }^{2}$ EKO PRIYO PURNOMO, ${ }^{3}$ AULIA NUR KASIWI \\ 1,2,3Master of Government Administration Affairs, Graduate Program, Universitas Muhammadiyah Yogyakarta. \\ Geblagan, Tamantirto, Kasihan, Bantul Regency, Special Region of Yogyakarta 55184 Indonesia \\ Correspondence author: ${ }^{1}$ resky.eka.psc19@mail.umy.ac.id
}

\begin{abstract}
In this era of the 21st century, political parties have many ways to develop a campaign, including on social media as a new medium to do a campaign. Partai Demokrasi Indonesia Perjuangan (PDI-P) has its own strategy toward social media to achieve their power in society. This research aims to discover the level of electability of PDI-P through Instagram, one of social media platforms being used to make social interaction with the public. Starting from Instagram, this research has decided three criteria: basic of election mode, media channels, and technological access to political party that can be seen by public. The analysis is conducted to a variety of large and small media outlets that analyze and explore things beyond political parties. This research uses Nvivo12 Plus as network analysis tools to identify and analyze data from Instagram related to PDI-P strategy. The results of this study show that social media has a significant role in pursuing and maintaining the power of political parties to stay strong in society's life. This research also develops a novelty, based on the results, that social media has a strong power to build a strategy and accept plurality in society's behavior, instead of building a strong branding of the political party itself and stand out as candidates.
\end{abstract}

Keywords: Electability, Political Parties, Social Media

\section{Introduction}

In a political concept, the products being marketed are political parties or individual candidates. A political party, instead of a candidate, can provide vision, mission, and programs in accordance with the needs of the community (Natasya Sitanggang \& Dharmawan, 2017). Also, politics is a campaign process of dialogical communication between political parties and the community (Firmanzah, 2008). The purpose of political communication is to create a shared understanding and perception between political parties and the public (David Sanjaya, 2016). McNair (2010) said that political parties measure their success not in the concept of profit, but the number of votes and power gained (Joyce Sandra, 2013). Political branding is considered as one of the effective paths to figure and deliver the face of political parties publicly (Eka
Prasetiyanto, 2019). Some factors that affect political participation of the community are the exposure of political socialization received by the community and socioeconomic status held by the community (Syarif, 2016). Political parties move forward to develop the strategy to gain power in public (Handayani, Sylvina, and Lestari, 2017).

The idea of political campaign is to lead the community offered by the candidates or prospective voters from political parties (Indrawan, 2017). On the other side, the scale of political image will give point for the candidate in competition with other candidates and political parties which also carry out their communication activities and public relations toward politics (Rusmulyadi \& Hafiar, 2018).

The value of political parties can be created as much as their potential in the community along with various strategies

Received: 2019-12-28, Revised: 2020-02-05, Accepted: 2020-12-16 
to win (Handayani, Sylvina, and Lestari, 2017). Even policies resulting from such political practices have created public frustration, which can be translated as public distrust in political parties, the ruling political elite, and formal and informal networks primarily in various democratic institutions (Margiansyah, 2019). Political parties measure their success not in the concept of profit, but the number of votes and power gained (McNair in Joyce Sandra, 2013). This political competition can occur at several levels. First, a competition between political parties. Second, individual competition at individual level. Third, competition on personal level as a politician, whether his/ her motivation is to become a legislator or member of people's representative in a state institution such as DPR RI or DPRD, where he/she have to face other political opponents (Muktiyo, 2014).

The digital media at this time is primarily used to demonstrate a user's ability to deliver patterns or what kind of styles he/she is going to wear that day. The degree of social media used is perceived to be the general public's standard of living. Social media, especially for political parties, is a new developing media considered to be very helpful in presenting the political party figure in national and international arena. Partai Demokrasi Indonesia-Perjuangan (PDI-P) is currently using social media as a platform for providing general political activity-related information. A variety of political styles, if they are carefully observed, can provide opportunities for political parties or anyone who look for electability or want to obtain the voice of society through social media at the time of campaign session. Since the beginning, the idea of democracy is about equal political power in public affairs, not just a procedure (Puspa Hestiantini \& Priyo Purnomo, 2018). Nowadays, through the power of social media, certain candidates can lead the electability as the future leader (Praselanova, 2018).

Social media is an online media where users can easily participate, share and create content including blogs, social networks, forums, and virtual worlds. Social networks and wikis are the most common forms of social media used by people around the world. Other opinion explained that social media is a tool to supports social interaction and create dialogical communication (Rizal, 2013). Social media has been existed in contemporary political dynamics, especially in modern election that presents different alternative in communicating, including as a legislative instrument, both to form public opinion, as well as a medium of interaction between parties and politicians and their constituents (Hasan, 2015). Currently, media ownership greatly influences the construction of news, which means the involvement of media owners in a political party will also significantly affect the objectivity of news content (Bricolage, 2015). Social media is a form of internet development.

According to data from the Ministry of Communication and Information Technology (Kemenkominfo) in 2013 (kominfo.com), internet users in Indonesia currently reach 63 million people (Ayun, 2015). There is an explanation about the form of communicationbased on history from oral, script, print, electronic (wired and wireless), and finally to digital communication (Chen in Akmal \& Salman, 2015). Andreas Kaplan and Michael Haenlein define social media as "a group of internet-based applications that are built on the foundation of ideology and Web 2.0 technology, and that enables the creation and exchange of user-generated content" (Miranda, 2017). The characteristics of social media are as follows (Cross, 2014): (1) Participation; (2) Openness; (3) Conversation; (4) Community; (5) Connectedness. This social media can be used to publish a definite form of activities carried out by a company so that these activities will get the attention from the audience and ultimately will build a positive image for the company (Rahadi, 2017). On the other side, the purpose of social media has been many and can be used to branding one's political image or a particular political party. Conversely, social media was also used as a symbolic battle media that deconstruct or degrade a person's political image or governmental institution (Rusmulyadi \& Hafiar, 2018).

Since the internet developed in Indonesia in 1990, political contributions become more settle on bargaining their position and to adapt in society (Hasfi, 2019). Along with the internet's existence in Indonesia, there are also studies on political communication and culture of communication that have impact on political party (Fajriyah, 2019). The highest political system can be seen as the most powerful system in the world, where political students learn about how the states build their power and the role of political communication that have impact on another side of the daily life (Shahreza, 2016). 
Political communication can be determined by several factors, such as communication ability, personal branding and figure, the background of communicators, and communication to reach the communication knowledge that is the choice of mode, channel selection, and access to technology. A political party needs to find out the right way to deliver its political communication straightforwardly toward social media to get the response from society as much as they are expected. Nevertheless, social media still has a lack from its users' side where the different in educational level make them respond differently to the knowledge or information being received and how they align with the technology. Mode selection is the determination of the type or style of a person to find out the elements received from social media itself, for example, formal mode and calm mode. It divides into two methods based on the pattern of communication on social media by political parties: essential or general information. Channel selection is the type of media used by political parties to provide information to the public, and they choose social media of Instagram. In Indonesia alone, Instagram users are classified as very many, reported by goodnewsfromindonesia.id, which reached $53,000,000$ users in 2018 and took the position of the 3rd largest in the world under the United States and Brazil. Access to technology used is based on a mobile phone application or an online web browser. Effective political communication is proven to produce a good response to the relationship between politicians and the community. In addition, it will increase personal electability as well as the political party itself. On the other side, the terracemaluku.com described social media as one of the mediums to bring down political rivals with methods of threats, lies, slander, and black or hoax campaigns (Syarifudin, 2019). This problem is vital in formulating participatory communication to emphasize a necessity for dialogues in strategic communication efforts, namely community involvement with normative social changes desired pragmatically for a replacement (Burhan, 2019). The intervention of social media is not just changing the direction of human knowledge, transparency, finance, logistics, and politics, but also religious order through sacred values in local religious expressions (Rijal, 2019). Political communication, intentionally or not, is conducted in a daily chat or conversation. Social media today is primarily used to insult, bully, attack, slander, and a medium to spread hatred by ignoring ethics, manners, norms, and rules (Lestari, 2017; Shahreza, 2016).

Nowadays, it is crucial to increase the electability of political parties using social media instead of increasing the electability during the election season. One of the political parties that actively use social media is PDI-P. This political party realizes that the role of social media is very influential in supporting the sustainability of the campaign. It becomes something interesting to be explored further, particularly on the communication patterns of PDI-P to strengthen and increase its electability during the 2019 elections by looking at aspects of fashion selection, channel selection, and access to technology to create the effectiveness of political communication.

The Breed (Social Control in The Newsroom) says that politics is who gets what, where, and how political values are transmitted with the authority, strength, and handheld; the effect of direct action to preserve and extend specific activities (Rizal, 2013). The significance of political parties is as a path to the top of leadership through party recruitment, which is in line with one of the roles of politics itself, namely political recruitment (Munawaroh Nugraha, Ketut Gunawan, and Alaydrus 2019). Social media is used to inform the public about and publish cadres who are nominated for the parliaments and other positions in government. In particular, communication interactions can be carried out in Instagram through its setting for voting calls. There is a correlation between the use of Instagram and visiting interest followers (D. Ahmadi \& Adzhani, 2019).

There are rules of linguistic politeness that have been described on social media and users are expected to comply with it (Kusmanto \& Purbawati, 2019). Different styles in conveying political expression can turn out into a conflict thus far-reaching significances and democratic values. There is even religious values involved in political disputes (Pamungkas \& Octavian, 2017). The rapid growth of information technology affects the actions and lifestyle of people, and this can also happen to the political situation where people with bad intention manipulate it and get all the benefits for himself/herself only (Septanto, 2018). The contestation and close political battles between rivals develop in social media from year to year causing reasonable concern (Fernandes, 2019). Social media can be a tool for taking the rivals down, 
from opposition to political goals.

Online media is not only changed the way information is transmitted, but also change how people view the displayed information (Juditha, 2018). The existence of social media such as Facebook, Twitter, blogs, Instagram, Path, BBM, and others, form a radical change in communication (Putra, 2017). Essentially, media is not a free source, a building agent (Hastjarjo, 2014), but may include society in public affairs (Irianti, 2018). Kominfo revealed that Internet users in Indonesia reached 63 million people. The total is divided into $95 \%$ of the network used for social media access (Ayun, 2015). Another view suggests there are four functions for the use of electronic media: providing information, educating, entertaining, and influencing. Social media can be a media for public officials to do voting, political debate, campaign processes, and provide advanced communication (Februri et al., 2018). Social media often follows the fulfillment of one's goals and engagement in the organization (Lihardja et al., 2017). Prabowo conveys his political communication through social media; it can be said that communicate politics digitally is an effective way to get the general public to understand and sympathize with the constituents (Besman, Adiputra, and Saputra, 2018).

Determine the direction of political communication as a way to increase political party electability is based on three essential things: the target type of society, casual or formal mode and platforms (Instagram) chosen, and access to technology. Effective political communication can be calculated to easily find out the political party's electability level. It is believed that effective political communication can create a good relationship between politicians and society.

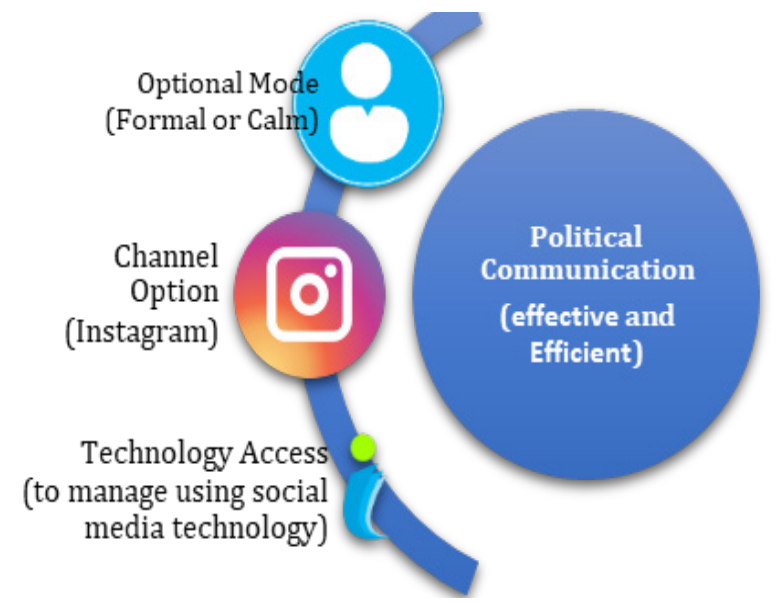

Figure 1: Framework of the Effectiveness of Political Communication
(Source: Juswil 2019)

The efficacy of political communication flow based on mode flow, choice of options, and access to technology are shown in figure 1. People use Instagram in both formal and casual ways. They appear in casual mode for social media topics or social attention, and this casual conversation mode in caption is more appealing to young people.

Instagram is one of the platforms or forums that can be used for political communication. Instagram is chosen because its functionality and interfaces are familiar to children, teens, and adults alike. Instagram is in great demand from everyone, performers, public figures, government officials, and even the President in almost all circles (Miranda, 2017). Like PDI-P today, the "Battle Culture" has an Instagram page for young people. It has been crafted primarily to encourage readers to enter the group by an invitation. Social media is described as "a community of Internet applications based on the Web 2.0 philosophy and technology that allow usergeneration to generate and share content " (Stieglitz \& Dang-Xuan, 2013). This study aims to analyze data from Instagram related to PDI-P electability and find out the level of electability of PDI-P through Instagram as a type of social media platform that can get interaction with the public. By using Instagram, this research has three criteria: Basic Election Mode, Media Channels, and Visible Political Party Existence Access Technology. Research analysis is conducted to a variety of large and small media which can be analyzed and further explored through this political party.

\section{Research Methodology}

The method used in this research is qualitative. Qualitative research can be interpreted as a study using many techniques. Systemic qualitative research is available in the form of interview script, survey questions, journals, registered observations or existing papers among other sources, which usually gathered through interviews (Suter, 2014). There are several stages carried out in this research as shown by figure 2 .

The data search in this study began with a literature review to find problems related to research and theories as well as data to support this research. The data obtained then made into a theoretical framework served as a guide for data collection and analysis. The researchers took data using NCapture and subsequently processed it 
directly with the help of Nvivo 12 plus data processing software. The results are analytical and adjusted to the existing framework as a result of the literature review conducted at the beginning, and then make conclusions after the analysis process is complete.

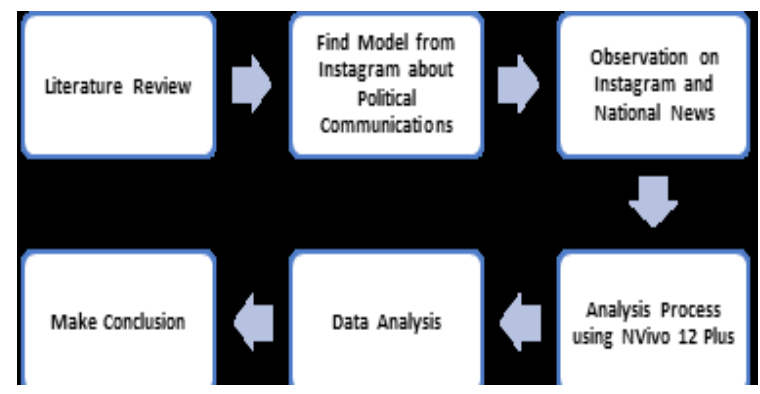

Figure 2 Flow of Research Methods

(Source: researcher, 2019)

\section{Results and Discussion \\ Option mode of Political Parties in Instagram}

PDI-P Political Party uses social media as a means to publicize prospective candidates (Bakal Calon or Balon in Indonesian language) to the broader community through social media, one of which is Instagram. Social media is used as a form of finding and increasing electability. There are three aspects used to determine the electability level of PDI-P political parties, including (1) Mode Selection; (2) Channel Selection; and (3) Access to Technology. Social media accounts managed by the PDI-P internal community provide an interactive form of campaign for digital social media users. It should be noted that everything presented by PDI-P on its social media has a positive impact on the party's vote because people's vote is the key to the party's success in giving new hope and fighting spirit.

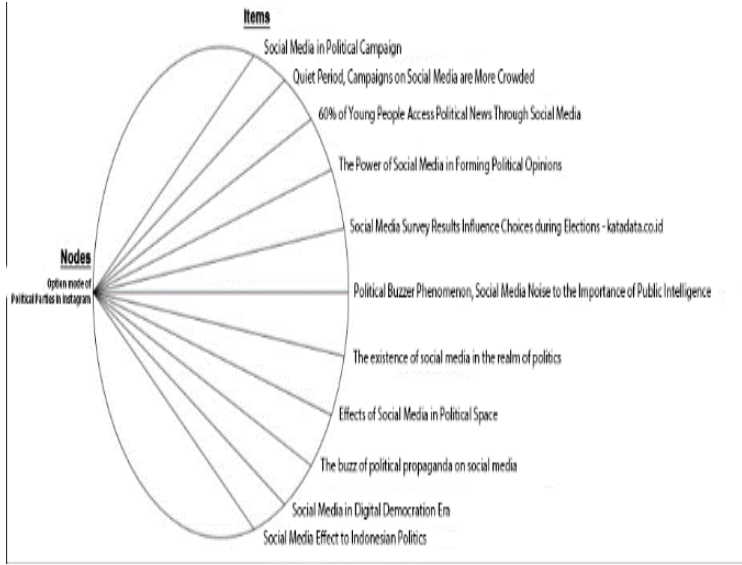

Figure 3. Political Mode

(Source: NVivo12 Plus, 2019)
Figure 3 explains a correlation of Political Style to Political Mode obtained from several sources. The eleven correlation lines show that the information collected discusses political style or mode. Katadata.com said that political form is proven by the figure of $60 \%$ of young people accessing political party news through social media. Social media is the power to shape public opinion. It means the style displayed on social media can lead to a relaxed and formal mode depending on the space since social media greatly influences the choice at the time of the election.

Therefore, the form of political style is determined by the effect of social media. But keep in mind that the digital democracy in social media era can bring connoisseurs or readers to civic type or style. Not only through television ads, official websites, and public promotions, the PDI-P party uses many social media to execute its digital promotions including Facebook, Twitter, Youtube, Instagram, and others. There is also a correlation between media types, media content, media exposure and social context in watching Youtube with the fulfillment of information needs (Ahmadi, Sabarina, \& Harahap, 2020). The media or party advertising site frequently used is of course Instagram. The application enables its users to share stories, details, and activities with other users.

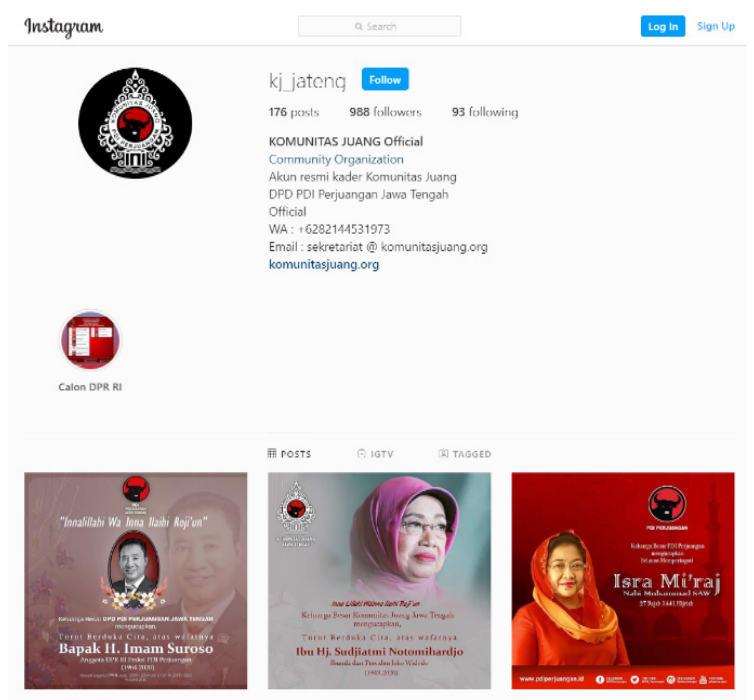

Figure 4 Instagram Account of Komunitas Juang

(Source: Instagram, 2019)

\section{Channel Option}

PDI-P has the largest youth-sector Instagram page, namely the Komunitas Juang in Central Java. According to the number of 
Regencies/Cities in the Central Java Region, the Instagram account is maintained and distributed throughout the Central Java region with a total of 35 Instagram account.

In figure 4 shows the Instagram social media used by the Komunitas Juang in Central Java Komunitas Juang is a Central Java to PDI-P youth training by unit region and Bambang Muryanto as a pioneer. The training took place mainly in six residencies, including Solo Raya, Semarang, Pekalongan, Banyumas, Kedu, Pati Raya, and also in other areas. The training program is carried out using a mentoring system that involves 11 individuals from each district and has 1 tutor assistant.

The number of named cadres is 4,286 people divided into eight groups. The Chairperson of PDI-P, Megawati Soekarno Putri, started this cadre at Gor Krida Satria Banyumas in 2014. The goal of the training is to be the front guard ready to prepare for the political year 2018-2019 by young people who are assigned to the Community of Combat. Therefore, different events will be shared on Instagram Group Fighting page to demonstrate the presence of the Fighting Team.

The foundation of the training team consists of 5 key points: 1) Party; (2) Bung Karno; (3) Nationalism; (4) Marhaenism; and (5) Winning Election. A slogan or jargon of "Salam Juang! Satu Jiwa, Satu Hati, Berjuang Membangun Negeri. Merdeka!!!!" and "Melu Memayu Hayuning Bhuwono" was generated from all the points.

As a result, in conjunction with the development of technology, the Komunitas Juang is trying to use Instagram as a means or media to publicize and make it widely available to young people to participate in the elections that have been held during the 2018-2019 preparations. In this way, young people will be encouraged to participate, even if they do not participate directly, they can simply participate in the community.

\section{Technology Access: Instagram vs News Information}

The formation of political form itself is based on the strong influence of social media that is used like Instagram as if the mode or political style used can be balanced if the intended target is the scope of the millennial or the elderly.
In figure 5, shown the social media and national news sources show the importance of social media to increase electability and attract sympathy from millennials. The phenomenon of political buzzer often makes noise to the significance of public intelligence.

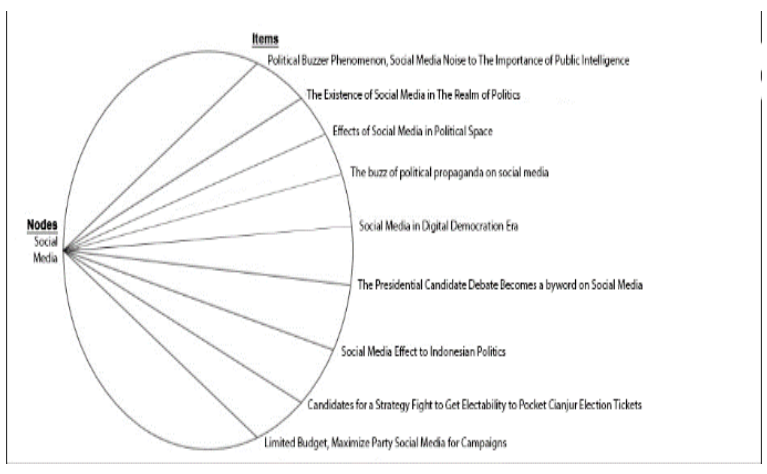

Figure 5. Instagram Social Media vs News Information

(Source: NVivo12 Plus, 2019)

Okenews.co.id said buzzers are working on several major social media platforms such as Facebook, Twitter, Instagram, and Whatsapp. However, it is also found that the government and political parties used private parties or contractors and politicians as personal staff to administrate and share their campaigns and messages. In this case, social media becomes a political realm to create a massive effect of propaganda so that digital democracy looks busy and being discussed in the era of social media. When the first presidential debate event becomes a motto on social media, it certainly raises the level of public knowledge as well as a millennial's understanding of the candidates chosen.

Prospective candidates share their strategies through a debat to achieve electability and secure the regional head election ticket. Therefore, some political parties including PDI-P maximize their social media as a money-saving medium for their campaigns. Through social media, the representation of figure of personal assortment is created using fashion lexicon, metaphor, and infographic mixed (Belawati, 2014). Young people or teenagers are unable to distinguish the good and the bad when it comes to smartphones. As if all the world's information is loaded and displayed on Instagram and they need to check it out daily. Instagram is key in reminding the public that the PDI-P is doing a political campaign. PDI-P has multiple accounts: the Komunitas Juang, Komunitas 
Banteng Muda, Banteng Muda Indonesia, Pandu Juang, Taruna Merah Putih to get millennial's voices, and the National Election Witness Board of PDI-P. Puntoadi said that social media users can share information, do collaborate, and establish relationships in the form of graphics and audiovisual (Eliya \& Zulaeha, 2017). Social media is used by political to attract sympathy from its users (Abdul Muqsith \& Prima Mulyasari, 2019). However, there are also other uses of social media such as Twitter to fight the hashtag war (\#) of illicit accounts, to avoid reporting wrong political parties.

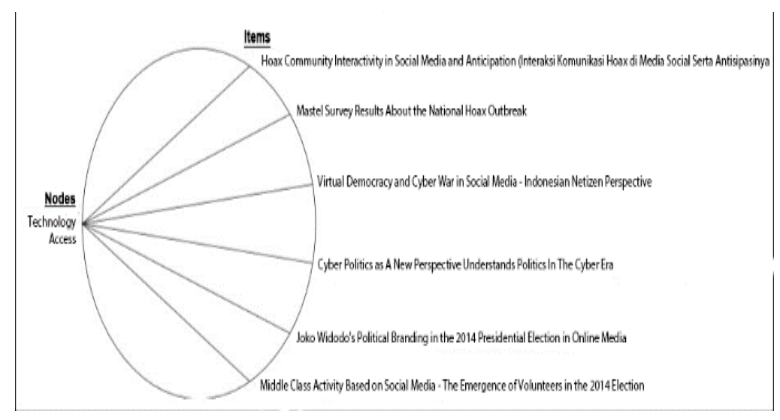

Figure 6. Correlation of Technology Access to News Information

(Source: researchers, Rachmandani 2019)

In figure 6 explains the correlation lines of Technology Access to news information which are sufficiently related to increasing the electability of political parties, especially the PDI-P. These lines are described with the aim to anticipating spreading of hoax on social media. Social media become media with a unique attraction for the political world, where the freedom of internet provides users to respond to political actors by giving ideas or even disseminating incorrect information (Fajriyah, 2019). PDI-P has its way to block access to technology if there is anything unusual, such as in the case of Virtual Democracy and Cyber War on social media.

Access to technology can create new perspectives in understanding politics in the cyber era, for example, the emergence of social media-based middle-class activism with the rise of volunteers in the 2014 election. Another example is the use of internet in running social media to conduct and find good PDI-P electability. Therefore, the high number of community participation via the internet and social media is believed to be able to create a substantial impact on the political sphere (Fajriyah, 2019).

\section{Conclusions}

The main goal of political parties is to reach electability by seeking and maintaining their community's sympathy and votes as much and as long as possible. This can be seen on several social media accounts that are deliberately created by the community as a media to do campaign for political parties and prospective candidates to compete at the democratic party in 2019. The political communication strategy carried out by the successful team aims to improve political parties' electability. In this case of research, PDI-P has political power and the right level of electability. No doubt that the way of campaigning through social media, particularly on Instagram, is the most favored by millennials through text, infographic, and audiovisual methods displayed. That way, the approach used can form effective and efficient communication to achieve the right level of party electability. Social media accounts managed by the PDI-P internal community provide an interactive form of campaign for social media users.

It should be noted that everything presented by PDI-P on its social media has a positive impact on the party's vote because the people's vote is the key to the party's success in giving a new form of hope and fighting spirit. Further research recommendations should be carried out with a deeper understanding of PDI-P political parties through social media so that it can provide more information in finding factors of access to information that most influence the electability of political parties and refinement the results by searching for factors that affect a party's social media.

\section{References}

Abdul Muqsith, M., \& Prima Mulyasari, A. (2019). Hubungan Pesan Sosialisasi Politik Dengan Citra Partai: Studi Kasus Akun Twitter@Pksejahtera. 2, 3-12.

Ahmadi, D., \& Adzhani, A. V. (2019). The use Instagram with visiting interest: The correlation between the use @ littlecollins.bdg Instagram with visiting interest. Journal of Physics: Conference Series, 1375(1), 1-6. https://doi. org/10.1088/1742-6596/1375/1/012055 Ahmadi, Dadi, Sabarina, C., \& Harahap, E. H. (2020). Implementation Information Technology Through Channel Youtube "Lampu Islam." 409(SoRes 2019), 
630-631. https://doi.org/10.2991/ assehr.k.200225.137

Akmal, F., \& Salman, A. (2015). Partisipasi politik belia secara 'Online' melalui ruang demokrasi maklumat media baru. Jurnal Komunikasi: Malaysian Journal of Communication, 31(1), 81-100.

Ayun, P. Q. (2015). Fenomena Remaja Menggunakan Media Sosial dalam Membentuk Identitas. CHANNEL Jurnal Komunikasi, 3(2), 1-16. https://doi. org/10.12928/channel.v3i2.3270

Belawati, T. (2014). Politik Wacana di Media Sosial Twitter Menjelang Pemilihan Presiden Indonesia 2014. Jurnalistik SMAN 1 Krian Sidoarjo, 39(1), 1-15. https://doi. org/10.4324/9781315853178

Besman, A., Adiputra, A. V., \& Saputra, S. J. (2018). President Joko Widodo Communication in the \#Baliaman Vlog. Jurnal Penelitian Komunikasi, 21(1), 43-56. https://doi.org/10.20422/jpk. v21i1.518

Bricolage, J. (2015). Jurnal Bricolage|Vol.1. No. 2|Desember 2015 | 1. 1(2), 1-27.

Burhan, A. B. (2019). Politik Strategis Berbasis Internet pada Akun Facebook Komunitas Petani Indonesia. Communicatus: Jurnal Ilmu Komunikasi, 1(2), 1-20. https://doi. org/10.15575/cjik.v1i2.5030

Cross, M. (2014). What is Social Media? Social Media Security, 1-20. https:// doi.org/10.1016/b978-1-59749-9866.00001-1

David Sanjaya, L. (2016). Kampanye Politik Public Relations untuk Pemilihan Walikota dan Wakil Walikota Solok Periode 20162021 divisi Creative Design Coordinator. June.

Eka Prasetiyanto, E. (2019). Branding Partai Politik (Studi Pada Tagline Bersih, Peduli Dan Profesional Dalam Membentuk Citra Partai Keadilan Sejahtera Di Mata Masyarakat). Ilmu Komunikasi Fakultas Isipol, Univesitas Brawijaya, 53(9), 1689-1699. https://doi.org/10.1017/ CBO9781107415324.004

Eliya, I., \& Zulaeha, I. (2017). Pola Komunikasi Politik Ganjar Pranowo dalam Perspektif Sosiolinguistik di Media Sosial Instagram Abstrak. Seloka : Jurnal Pendidikan Bahasa Dan Sastra Indonesia, 6(3), 286-296.

Fajriyah, P. (2019). Virtual Democracy: Study on Political Communication of Hate speech and Hoax in Presidential Election 2019 Through Social Media Jurnal Virtual Democracy : Study on Political Communication of Hate speech and Hoax in Presidential Election 2019 Through Socia. IImu Politik, Fakultas IImu Sosial Dan Ilmu Politik, Universitas Airlangga, Surabaya, 22-49.

Februri, M. R., Idris, A., \& Alaydrus, A. (2018). Pengaruh Media Elektronik Terhadap Pilkada Kota Samarinda Tahun 2015. 6(3), 1159-1168.

Fernandes, A. (2019). Politik Identitas dalam Pemilu 2019 : Proyeksi dan Efektivitas. Centre For Strategic And International Studies, 1, 1-10.

Firmanzah. (2008). Marketing Politik: Antara Pemahaman dan Realitas. Yayasan Pustaka Obor Indonesia.

Handayani, F., Sylvina, V., \& Lestari, A. (2017). Analisis Strategi Komunikasi Pemasaran Politik Hary Tanoesoedibjo (Studi Kasus Program UMKM sebagai Political Branding Partai Persatuan Indonesia (Perindo)) Arnoldus. Prosiding Konferensi Nasional Komunikasi, 01(01), 552-558.

Hasan, K. (2015). Bahan ajar handout Komunikasi Politik New Media Dan Komunikasi Politik Kontemporer 1. 1-13.

Hasfi, N. (2019). Komunikasi Politik Di Era Digital. Politika: Jurnal Ilmu Politik, 10(1), 5-10.

Hastjarjo, Y. A. W. \& S. (2014). Analisis Framing Pemberitaan Deklarasi Pencapresan Jokowi di Media Massa (framing Media Massa Surat Kabar Terhadap Pemberitaan Deklarasi Pencapresan Jokowi di Media Indonesia, Kompas, Republika dan Jawa Pos). 1-19.

Indrawan, R. M. J. (2017). Dampak Komunikasi Politik Dan Opini Publik Terhadap Perilaku Masyarakat. WACANA, Jurnal IImiah IImu Komunikasi, 16(2), 171. https://doi. org/10.32509/wacana.v16i2.14

Irianti, R. (2018). Hoax Dan Pergeseran Preferensi Sosial Politik Mahasiswa. 2, 20.

Joyce Sandra, L. (2013). Political Branding Jokowi Selama Masa Kampanye Pemilu Gubernur Dki Jakarta. Jurnal E-Komunikasi, 1(2). www.twitter.com/ jokowi_do2

Juditha, C. (2018). Hoax Communication Interactivity in Social Media and Anticipation (Interaksi Komunikasi Hoax di Media Sosial serta Antisipasinya). Journal Pekommas, 3(1), 31. https://doi. org/10.30818/jpkm.2018.2030104

Kusmanto, H., \& Purbawati, C. (2019). Impoliteness Commenting On Social Media Instagram: Politicopragmatic Study Ketidaksopanan. 217-227. https://doi. org/10.22216/jk.v3i2.4338

Lestari, P. (2017). Semangat Kebangsaan 
dalam Media Sosial Indonesia.

Lihardja, N., Setiawan, K., \& Suparman, M. Y. (2017). Partisipasi politik generasi muda tionghoa paska orde baru. 137-146.

Margiansyah, D. (2019). Populisme di Indonesia Kontemporer: Transformasi Persaingan Populisme dan Konsekuensinya dalam Dinamika Kontestasi Politik Menjelang Pemilu 2019. Jurnal Penelitian Politik, 16(1), 47-68.

Miranda, S. (2017). Pengaruh Instagram Sebagai Media Online Shopping Fashion Terhadap Perilaku Konsumtif Mahasiswi Fakultas Ilmu Sosial Dan Ilmu Politik Universitas Riau. Standar Kinerja Supervisor Pada Housekeeping Departement Di Grand Jatra Hotel Pekanbaru, 4(2), 1-15.

Muktiyo, W. (2014). Strategi Komunikasi Politik Calon Legislatif Partai Golkar dalam Memenangkan Pemilihan Umum 2014 di Kabupaten Sragen. 273-286.

Munawaroh NUgraha, S., Ketut Gunawan, I., \& Alaydrus, A. (2019). Strategi Partai Demokrat Dalam Perekrutan Anggota Partai Demokrat Di Kota Samarinda. 7(1), 39-50.

Natasya Sitanggang, H. B., \& Dharmawan, A. (2017). Strategi Marketing Hary Tanoesoedibjo Dalam Usaha Membangun Personal Branding Politik. International Conference on Computing, Engineering, and Design (ICCED), 3-7.

Pamungkas, A. S., \& Octavian, G. (2017). Jurnal Pemikiran Sosiologi Volume 4 No. 2 , Agustus 2017. Jurnal Pemikiran Sosiologi, 4(2), 65-87.

Praselanova, R. (2018). WASILATUNA : Jurnal Komunikasi dan Penyiaran Islam. 01(1), 75-102.

Puspa Hestiantini, A., \& Priyo Purnomo, E. (2018). Marginalisasi Kepentingan Kelas dalam Demokrasi Indonesia. June, 0-14.

Putra, F. D. (2017). Psikologi Cyber Media Seni Komunikasi Propaganda Menggunakan Media Sosial Dalam Kaitannya Dengan Isu Sara Di Indonesia. CHANNEL: Jurnal Komunikasi, 5(2), 91-108. https://doi. org/10.12928/channel.v5i2.7978

Rahadi, D. R. (2017). Perilaku Pengguna Dan Informasi Hoax Di Media Sosial. Jurnal
Manajemen Dan Kewirausahaan, 5(1), 58-70. https://doi.org/10.26905/jmdk. v5i1.1342

Rijal, A. (2019). Politik Tuan Guru Versus Politik Media " Pilpres 2019 Di Lombok " Antara Dakwah. 16(2), 21-44.

Rizal, M. (2013). Analisis Framing Pemberitaan Politik Capres Dan Cawapres Di Media Sosial Pada Akun detik.com. Journal of Chemical Information and Modeling, 53(9), 1689-1699. https://doi.org/10.1017/ CBO9781107415324.004

Rusmulyadi, R., \& Hafiar, H. (2018). Dekonstruksi Citra Politik Jokowi Dalam Media Sosial. PRofesi Humas: Jurnal IImiah IImu Hubungan Masyarakat, 3(1), 120. https://doi.org/10.24198/prh. v3i1.16729

Septanto, H. (2018). Pengaruh Hoax dan Ujaran Kebencian Sebuah Cyber Crime dengan Teknologi Sederhana di Kehidupan Sosial Masyarakat. Jurnal Sains Dan Teknologi, 5(2), 157-162. http://research. kalbis.ac.id/Research/Files/Article/Full/ LCSCVZI11HG7VORWMAFRW7GH3.pdf

Shahreza, M. (2016). Etika Komunikasi Politik. https://www. researchgate.net/ publication/326144065_Ethics_On_ Political_Communication

Stieglitz, S., \& Dang-Xuan, L. (2013). Social media and political communication: a social media analytics framework. Social Network Analysis and Mining, 3(4), 1277-1291. https://doi.org/10.1007/ s13278-012-0079-3

Suter, W. (2014). Qualitative Data, Analysis, and Design. Introduction to Educational Research: A Critical Thinking Approach, 342-386. https://doi. org/10.4135/9781483384443.n12

Syarif, M. A. (2016). Pengaruh Sosialisasi Politik dan Status Sosial Ekonomi Terhadap Partisipasi Politik Pada Pemilihan Walikota 2015 di Kelurahan Air Putih Kota Samarinda. E-Journal Pemerintahan Integratif, 4(4), 547-561. https://goo.gl/ YZtaVE

Syarifudin. (2019). Metode Dakwah Mencegah Bullying Komunikasi Politik Di Media Sosial. Jurnal Khazanah Keagamaan, 7(1), $35-48$. 